\title{
ПРОЕКТНІ ТЕХНОЛОГІЇ ДЛЯ ПРОФЕСІЙНОЇ ПІДГОТОВКИ МАЙБУТНІХ КВАЛІФІКОВАНИХ РОБІТНИКІВ АГРАРНОЇ, БУДІВЕЛЬНОЇ ТА АВТОТРАНСПОРТНОЇ ГАЛУЗЕЙ
}

Наукова доповідь на засіданні Президії НАПН України 17 жовтня 2019 р. https://doi.org/10.37472/2707-305X-2019-1-1-2-2

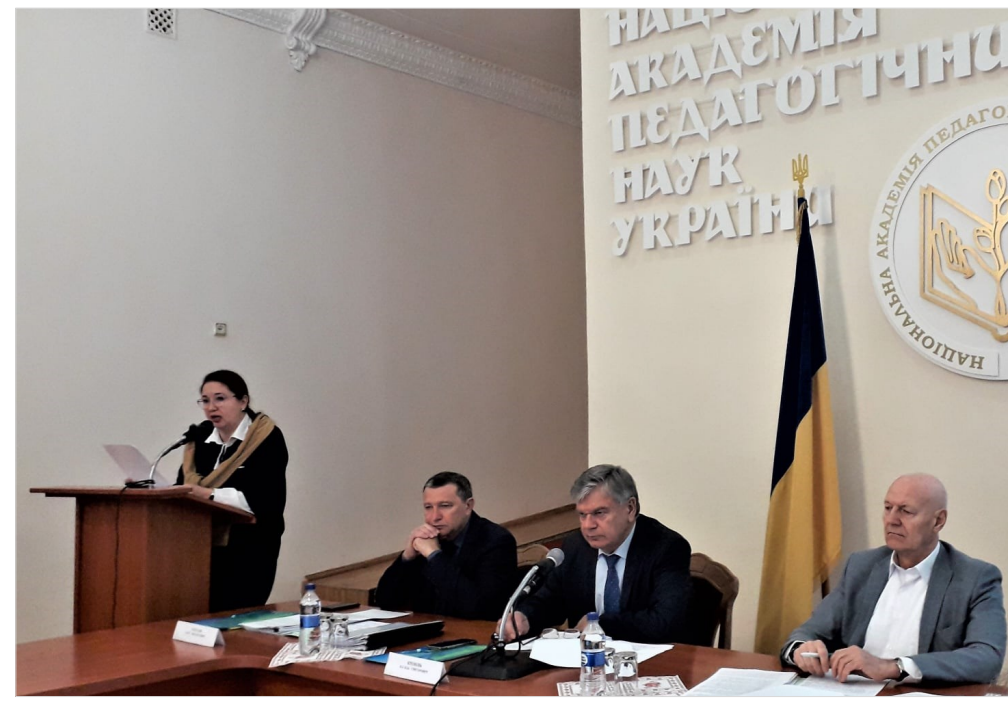

КУЛАЛАЄВА Наталя Валеріївна кандидат хімічних наук, доцент, завідувач лабораторії технологій професійного навчання Інституту професійно-технічної освіти Національної академії педагогічних наук України, м. Київ, Україна

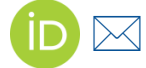

\section{РОМАНОВА Ганна Миколаївна} доктор педагогічних наук, професор, заступник директора з наукової роботи Інституту профресійнотехнічної освіти Національної академії педагогічних наук України, м. Київ, Україна

Анотація. У доповіді оприлюднено результати наукового дослідження «Методичні засади розроблення проектних технологій для професійної підготовки майбутніх кваліфікованих робітників аграрної, будівельної та автотранспортної галузей», виконаного співробітниками лабораторії технологій професійного навчання Інституту профресійно-технічної освіти НАПН України протягом 2016-2018 рр. Проаналізовано досвід застосування проектних технологій у професійній підготовиі кваліфікованих робітників; визначено методичні засади розроблення проектних технологій для їхньої професійної підготовки. Обгрунтовано методологічні підходи до проектного професійного навчання у закладах професійної (професійно-технічної) освіти. Наведено методики розроблення проектних технологій професійного навчання майбутніх кваліфікованих робітників аграрної, будівельної і автотранспортної галузей, організації проектної діяльності у 3П(Пт)О, оцінювання результатів проектного професійного навчання учнів. Представлено проектні технології для професійної підготовки майбутніх кваліфікованих робітників (інформаційно-аналітичну, практико-орієнтовану, дослідно -пошукову, творчо-інновачійну, соціально-виховну). Показано експериментальну перевірку їх результативності шляхом дослідження рівнів готовності педагогічних працівників до розроблення і застосування проектних технологій, і учнів - до проектного профресійного навчання.

Ключові слова: проектні технології; професійна підготовка; майбутні кваліфріковані робітники; проектне професійне навчання.

Необхідність цілісного впровадження у професійну (професійно-технічну) освіту інноваційних педагогічних технологій, зокрема проектних, зумовила актуальність теми дослідження
«Методичні засади розроблення проектних технологій для професійної підготовки майбутніх кваліфікованих робітників аграрної, будівельної та автотранспортної галузей». Робота виконува- 
лася співробітниками лабораторії технологій професійного навчання Інституту професійнотехнічної освіти Національної академії педагогічних наук України протягом 2016-2018 рр.

Його мета полягала в розробленні, експериментальній перевірці та впровадженні проектних технологій у закладах професійної (професійнотехнічної) освіти (далі - ЗП(ПТ)О) для вдосконалення якості професійної підготовки майбутніх кваліфікованих робітників аграрної, будівельної та автотранспортної галузей з урахуванням положень Стратегії сталого розвитку «Україна - 2020». Для ії досягнення визначено такі завдання: з'ясувати стан дослідженості проблеми та досвід застосування проектних технологій у професійній підготовці кваліфікованих робітників; обґрунтувати концепцію проектного професійного навчання у ЗП(ПТ)О; створити методики розроблення проектних технологій професійного навчання; розробити проектні технології для професійної підготовки майбутніх кваліфікованих робітників та експериментально перевірити їх результативність; підготувати і впровадити у ЗП(ПТ)О методичні рекомендації для педагогічних працівників щодо розроблення та використання проектних технологій професійного навчання у підготовці кваліфікованих робітників. Педагогічний експеримент з реалізації завдань проводили на базі сімнадцяти установ, серед яких: сім закладів професійної (професійно-технічної) освіти, вісім обласних та м. Києва навчально(науково)-методичних центрів (кабінетів) професійно-технічної освіти, два заклади вищої освіти. Наукове дослідження проводилося в три етапи (констатувальний, формувальний, узагальнювальний).

Метою статті є оприлюднення результатів наукового дослідження «Методичні засади розроблення проектних технологій для професійної підготовки майбутніх кваліфікованих робітників аграрної, будівельної та автотранспортної галузей», виконаного співробітниками лабораторії технологій професійного навчання Інституту професійно-технічної освіти НАПН України впродовж 20162018 років для використання цих результатів науковцями та педагогічною спільнотою України.

Метод проектів активно почали використовувати у 20-х роках минулого століття в США (В. Кілпатрик, Дж. Дьюї). За його допомогою педагоги організовували цілеспрямовану діяльність дітей з урахуванням їхніх особистих інтересів і потреб. В «Українському педагогічному словнику» визначено (Гончаренко, 1997, с. 205): «Метод проектів - організація навчання, за якої учні набувають знань і навичок у процесі планування й виконання практичних завдань - проектів». Наприкінці 80-х років XX століття виник новий напрям в освіті - продуктивне навчання, що ґрунтується на методі проектів. Сучасні науковці (Barron \& Darling-Hammond, Thomas) продовжують досліджувати цей метод в освіті. За визначенням Buck Institute for Education, проектне навчання - це метод, навчаючись за яким, учні, певний час досліджуючи і реагуючи на справжні, цікаві та складні питання, отримують потрібні знання та навички. Отже, особливістю проектного навчання є самостійне здобуття учнями нових знань під час їхньої продуктивної діяльності (вироблення ними конкретного продукту). За П. Лузаном, навчальний проект - це комплекс пошукових, розрахункових, дослідницьких, графічних та інших видів робіт, що виконуються учнями самостійно за організаційно-консультативної підтримки викладача з метою практичного чи теоретичного розв'язання проблеми (Лузан, Манько, Нестерова, Романова, 2014, с. 98).

На констатувальному етапі дослідження нами було обґрунтовано методологічні підходи до проектного професійного навчання у ЗП(ПТ)О (Аніщенко та ін., 2019): системний (цілісно розглядає проектну діяльністю учнів ЗП(Пт)О як систему, що динамічно змінюється в процесі взаємодії ії суб'єктів й під впливом навколишнього середовища); діяльнісний (забезпечує спрямованість мети проектної діяльності учнів на конкретний об'єкт, яка досягається сукупністю певних методів, засобів і дій через діяльність педагога і суб'єктів проектного навчання, що приводить до певного запланованого результату); особистіснорозвивальний (сприяє розвитку творчої ініціативи учнів, їхньої самостійності в проектному навчанні, самореалізації, створенню освітнього простору для їхньої індивідуалізації, самовизначення, саморозвитку тощо); компетентнісний (відповідає за формування в учнів компетентностей (загальнопрофесійних, професійних і ключових) упродовж проектного професійного навчання); технологічний (забезпечує різноманіття проектних технологій, передбачає використання системи раціональних способів у досягненні поставлених цілей, взаємодію і цілісність організаційної форми, дидактичного процесу, гарантованого кінцевого результату, алгоритмізацію спільної діяльності педагога та учнів); контекстний (сприяє створенню професійного контексту, що забезпе- 
чує особистісне включення учнів у навчальну діяльність та стимулює розвиток їхньої професійної спрямованості); субб'єктно-продуктивний (визначає у професійній підготовці провідну роль становлення суб'єктності особистості як здатності до проектування власного професійного розвитку та створення суспільно-корисних продуктів діяльності); процесний (регламентує й уніфікує дії суб' єктів проектної діяльності з описом вхідних і вихідних параметрів); інтегративний (дає можливість учням краще розуміти причинно-наслідкові зв'язки у досліджуваних явищах і процесах через інтегрування в проектній діяльності відповідних знань і вмінь із різних предметів).

Уточнено зміст основних категорій: «методичні засади розроблення проектних технологій», «проектна діяльність учнів 3П(Пт)О», «проектне професійне навчання у ЗП(ПТ)О», «проектна технологія професійного навчання», «готовність педагогів ЗП(ПТ)О до розроблення проектних технологій професійного навчання», «готовність учнів ЗП(ПТ)О до проектної діяльності». Визначено методичні засади розроблення проектних технологій для професійної підготовки кваліфікованих робітників, а саме: цілі розроблення проектних технологій визначаються з урахуванням соціального запиту, вимог ринку праці, а також особистісних потреб і можливостей здобувачів професійної (професійно-технічної) освіти; відбір і структурування змісту проектних технологій ґрунтується на використанні комплексу методологічних підходів, дидактичних принципів, галузевої специфіки професійної підготовки та враховує види навчально-пізнавальної діяльності учнів закладів професійної (професійно-технічної) освіти; успішна реалізація проектних технологій уможливлюється застосуванням евристичних, проблемно-пошукових, дослідницьких та інтерактивних методів навчання, технік розвитку критичного мислення, IKT, форм колективної творчої діяльності та взаємодії; результативність проектних технологій забезпечується використанням дидактичних комплексів, методичного інструментарію, ефективним управлінням та тренінговим навчанням педагогічних працівників і учнів закладів професійної (професійно-технічної) освіти.

Проектна діяльність учнів у ЗП(ПТ)О - це вид самостійно-пошукової, професійно орієнтованої навчальної діяльності, що здійснюється учнем або групою учнів під керівництвом педагога, однак без його безпосередньої участі, та завер- шується створенням конкретного творчого продукту.

Проектне професійне навчання у ЗП(Пт)О навчально-пізнавальна самостійна діяльність учнів за участі педагога як координатора, спрямована на результат, що досягається завдяки розв'язанню теоретично чи практично значущого для них фахового завдання.

Проектна технологія професійного навчання упорядкована і систематизована продуктивна пошукова діяльність учнів 3П(ПТ)О під керівництвом педагогів, у процесі якої вони індивідуально, в парах або в підгрупах проектують і виконують пізнавальні та практичні завдання, в результаті чого отримується конкретний творчий продукт. Видами проектних технологій професійного навчання $€$ : інформаційні, практико-орієнтовані, соціальні, дослідницькі, творчі тощо.

Готовність педагогів ЗП(ПТ)О до розроблення проектних технологій професійного навчання інтегративне особистісне утворення педагога, що охоплює мотиви, цінності, професійну Я-концепцію, професійно важливі якості, професійні знання, вміння, навички, які забезпечують результативне керівництво проектною діяльністю учнів. Структурні компоненти означеної готовності : мотиваційно-ціннісний, особистісний, пізнавальний і діяльнісний.

Готовність учнів ЗП(ПТ)О до проектної діяльності - інтегративне особистісне утворення учня ЗП(ПТ)О, що охоплює мотиви, цінності, професійно важливі якості, професійні знання, уміння, навички, що забезпечують результативну проектну діяльність. Структурні компоненти означеної готовності: мотиваційний, змістовий та особистісно-діяльнісний.

Проведено експертне оцінювання (SWOTаналіз) застосування проектних технологій у професійній підготовці кваліфікованих робітників аграрної, будівельної та автотранспортної галузей. На його основі визначено організаційнопедагогічні умови розроблення проектних технологій для професійної підготовки кваліфікованих робітників: цілеспрямована мотивація учнів до проектного професійного навчання; створення сприятливого для проектного професійного навчання інноваційного освітнього середовища; формування готовності педагогів та учнів до проектної діяльності; підготовка навчально-методичних матеріалів і дидактичних комплексів для проектного професійного навчання. 
Здійснено аналіз стану використання проектних технологій у професійній підготовці кваліфікованих робітників аграрної, будівельної й автотранспортної галузей та готовності педагогів і учнів ЗП(ПТ)О до проектної діяльності. У дослідженні взяли участь 2184 педагогічних працівника та 6611 учнів 3П(Пт)О.

Доведено, що особливістю проектних технологій для професійної підготовки кваліфікованих робітників $€$ їх розвивальна функція - розвиток дослідницьких навичок учнів, здатності до самоосвіти, сприяння професійному розвитку, формування професійно важливих якостей. Виявлено вплив цих технологій на формування в майбутніх фахівців затребуваних на сучасному ринку праці “м'яких» навичок (soft-skills), серед яких: креативність, критичне мислення, емоційний інтелект, комунікативні здібності, здатність до взаємодії. 3'ясовано, що застаріла матеріально-технічна база та низький рівень готовності учнів ЗП(Пт)О до проектної діяльності унеможливлює широке застосування проектних технологій у професійній підготовці кваліфікованих робітників.

Більшість педагогів використовують проектні технології у професійній підготовці майбутніх фахівців фрагментарно; лише п'ята частина опитаних викладачів розробляє їх постійно й успішно. Загалом, найбільш активно використовують проектні технології викладачі предметів загальнопрофесійної і природничо-математичної підготовки, а щодо галузевого спрямування - педагоги 3П (ПТ)О, які готують кваліфікованих робітників будівельної галузі. В інформаційних і дослідницьких проектах здебільшого беруть участь майбутні кваліфіковані робітники аграрної і автотранспортної галузей, у практико-орієнтованих і творчих - майбутні будівельники. Водночас, недостатньо використовуються міждисциплінарні проекти. Широко застосовуються в ЗП(ПТ)О соціальні проекти, що сприяють розвитку в учнів позитивних особистісних якостей, формуванню їхньої громадянської позиції.

Педагогічні працівники 3П(ПТ)О мають переважно середній рівень готовності до розроблення проектних технологій для професійної підготовки кваліфікованих робітників. Передусім у них сформований мотиваційно-ціннісний компонент готовності. Це зумовлює необхідність посилення уваги до розвитку готовності педагогів до розроблення проектних технологій, що доцільно здійснювати у тренінговій формі.
За результатами дослідження встановлено, що значна частина учнів має середній рівень готовності до проектної діяльності. Мотиваційний компонент цієї готовності сформований більшою мірою, а особистісно-діяльнісний компонент потребує подальшого розвитку. Отже, у процесі професійного навчання необхідно здійснювати підготовку учнів до проектної діяльності на основі тренінгів, виконання групових, міждисциплінарних, професійно спрямованих проектів.

Результати, одержані на констатувальному етапі експерименту, враховано під час обґрунтування концепції проектного професійного навчання в 3П(ПТ)О, на яку отримано авторське свідоцтво. Ії̈ інноваційність полягає у сприянні формуванню фахівців нового типу як особистостей, професіоналів, громадян, розвитку готовності педагогів до запровадження проектної діяльності; розробленню навчально-методичних матеріалів для проектного професійного навчання.

На формувальному етапі створено та впроваджено в 3П(ПТ)О методики: розроблення проектних технологій професійного навчання майбутніх кваліфікованих робітників аграрної, будівельної і автотранспортної галузей, що реалізується на різних етапах (діагностувально-прогностичному, проектувальному, організаційному, оціннорефлексивному); організації проектної діяльності у ЗП(ПТ)О; оцінювання результатів проектного професійного навчання учнів.

На основі методичного інструментарію розроблено проектні технології професійної підготовки кваліфікованих робітників аграрної, будівельної та автотранспортної галузей (Глущенко та ін., 2019), спільними ознаками яких є: спрямованість на формування загальнопрофесійних, професійних і ключових компетентностей; розвиток суб' єктності учнів (їхніх особистісних, громадянських і професійних якостей); забезпечення продуктивної діяльності, творчий, дослідницький і міждисциплінарний зміст професійного навчання. Відмінності між ними зумовлені галузевою специфікою професійної діяльності. Інформаційноаналітична технологія спрямована на формування інформаційно-аналітичної компетентності учнів, передбачає завдання, пов'язані з пошуком навчальної інформації в мережі Інтернет. Практико-орієнтована технологія забезпечує відпрацювання учнями професійних умінь і навичок під час створення проектного продукту, що заздалегідь визначений і може використовуватися, відповідно, в житті групи, ЗП(Пт)О, мікрорайону, міста та 
держави. Дослідно-пошукова - орієнтована на проведення учнями досліджень для вирішення певної наукової проблеми. Творчо-інноваційна передбачає створення учнями ЗП(ПТ)О якісно нових проектних продуктів, що уможливлює самостійне здобуття необхідних для цього знань, виявлення власних здібностей, самовираження. Соціально-виховна - орієнтована на формування в учнів «м'яких» навичок (soft-skills) у процесі розв'язання учасниками проектів актуальних соціальних проблем.

Експериментальна перевірка результативності запропонованих технологій здійснювалася шляхом дослідження рівнів готовності педагогічних працівників до розроблення і застосування проектних технологій та учнів - до проектного професійного навчання. 3 метою розвитку готовності педагогічних працівників до розроблення та застосування проектних технологій для професійної підготовки кваліфікованих робітників та формування готовності учнів до проектного навчання проводилися тренінг-курси «Підготовка педагогічних працівників професійно-технічних навчальних закладів до розроблення та застосування проектних технологій професійного навчання» (Аніщенко та ін., 2019) (650 педагогічних працівників, у т.ч. 250 майстрів виробничого навчання) та «Проектна діяльність учнів професійнотехнічних навчальних закладів» (Аніщенко та ін., 2018) (1368 учнів). У рамках дослідження проведено два експерименти Всеукраїнського рівня («Технологія проектного навчання у професійній підготовці кваліфікованих робітників автотранспортної галузі» - на базі Навчально-наукового центру професійно-технічної освіти НАПН України; «Формування енергоефективної компетентності майбутніх кваліфікованих робітників будівельного профілю на основі технології проектного навчання» - на базі Кам'янського професійного ліцею Дніпропетровської області (2016-2018рр.). Це сприяло помітному підвищенню на 20,5 \% рівня готовності педагогічних працівників до розроблення й застосування проектних технологій для професійної підготовки кваліфікованих робітників та сформованості на 16,7\% готовності учнів до проектного професійного навчання.

Доведено, що розроблені проектні технології $€$ одними з найзатребуваніших учнями, оскільки дають їм змогу спробувати власні сили в управлінні самонавчанням, досить швидко побачити результати власної праці, виявити власну громадянську позицію та розвинути лідерські/ партнерські якості. Це підтверджується активною участю учнівських колективів ЗП(ПТ)О в проведеному співробітниками Інституту в рамках міжнародного проекту ЕкоБРУ 543707-TEMPUS-1-20131-DE-TEMPUS-JPHES програми Європейської комісії Темпус IV Всеукраїнському екологічному конкурсі проектів «Збережемо Землю для наступних поколінь» для учнів (студентів) ЗП(ПТ)О. На конкурс було подано 57 проектів з 14 областей України. Найкращі проекти за підтримки Європейської комісії опубліковано в збірнику «Екоорієнтовані технології професійного навчання».

Співробітники лабораторії брали участь у семінарах-тренінгах «Pedagogy in higher education», що проводилися у рамках міжнародного проекту Erasmus+ Capacity Building Project «Improving teacher education for applied learning in the field of VET» («Удосконалення практико-орієнтованої підготовки викладачів професійної освіти і навчання»).

На узагальнювальному етапі систематизовано й узагальнено результати дослідження; сформульовано висновки, запропоновано методичні рекомендації (Герлянд та ін., 2016), завершено роботу над рукописами монографії (Аніщенко та ін., 2019), двох навчальних посібників, що отримали гриф МОН України (для учнів ЗП(ПТ)О (Аніщенко та ін., 2018), для педагогічних працівників ЗП(ПТ)О (Аніщенко та ін., 2019)) і довідника (Глущенко та ін., 2019); здійснено їх експертне оцінювання.

Отже, в процесі дослідження: вивчено досвід застосування проектних технологій у професійній підготовці кваліфікованих робітників; визначено методичні засади розроблення проектних технологій для професійної підготовки кваліфікованих робітників; обґрунтовано методологічні підходи до проектного професійного навчання у ЗП(Пт)О; створено методики розроблення проектних технологій професійного навчання майбутніх кваліфікованих робітників аграрної, будівельної і автотранспортної галузей, організації проектної діяльності у ЗП(ПТ)О, оцінювання результатів проектного професійного навчання учнів; розроблено проектні технології для професійної підготовки майбутніх кваліфікованих робітників (інформаційно-аналітичну, практико-орієнтовану, дослідно-пошукову, творчо-інноваційну, соціально-виховну) та експериментально перевірено їх результативність шляхом дослідження рівнів готовності педагогічних працівників до розроблення і застосування проектних технологій і учнів - 
до проектного професійного навчання; підготовлено та впроваджено у ЗП(ПТ)О методичні рекомендації для педагогічних працівників щодо розроблення та використання проектних технологій професійного навчання у підготовці кваліфікованих робітників.

\section{СПИСОК ВИКОРИСТАНИХ ДЖЕРЕЛ}

Аніщенко, В.М., Артюшина, М.В., Герлянд, Т.М., Кулалаєва, Н.В. (Ред.), Пащенко, Т.М. та ін. (2019). Теорія і практика проектного навчання у професійно-технічних навчальних закладах : монографія. Житомир: Полісся.

Аніщенко, В.М., Артюшина, М.В., Герлянд, Т.М., Кулалаєва, Н.В. (Ред.), Шимановський, М.М. та ін. (2018). Проектна діяльність учнів професійнотехнічних навчальних закладів: тренінг-курс : навч. посіб. Житомир: Полісся.

Аніщенко, В.М., Кулалаєва, Н.В., Романова, Г.М. (Ред.), Пащенко, Т.М., Шимановський, М.М. та ін. (2019). Підготовка педагогічних працівників професійно- технічних навчальних закладів до розроблення та застосування проектних технологій професійного навчання: тренінг курс : навч. посіб. Житомир : Полісся.

Герлянд, Т.М. (Ред.), Кулалаєва, Н.В., Пащенко, Т.М., Романова, Г.М., \& Романов, Л.А. (2016). Веб-квест у професійному навчанні: методичні рекомендації для педагогічних працівників професійно-технічних навчальних закладів : метод. рек. Київ: ІПТО НАПН України.

Глущенко, О.В., Романов, Л.А. (Ред.), Пащенко, Т.М., Пятничук, Т.В., \& Шимановський, М.М. (2019). Проектні технології навчання учнів профчеійних (професійно-технічних) навчальних закладів : довідник. Житомир: Полісся.

Гончаренко, С.У. (1997). Український педагогічний словник; Світлана Головко (Ред.). Київ: Либідь.

Лузан, П.Г., Манько, В.М., Нестерова, Л.В, \& Романова, Г.М. (Ред.). (2014). Теорія і практика впровадження інноваційних технологій навчання у професійну підготовку кваліфікованих робітників : монографія. Київ: ТОВ «НВП Поліграфсервіс».

\section{PROJECT TECHNOLOGIES FOR PROFESSIONAL TRAINING OF FUTURE QUALIFIED WORKERS IN THE AGRICULTURAL, CONSTRUCTION AND MOTOR TRANSPORT INDUSTRIES \\ Scientific report at the Meeting of the Presidium of the National \\ Academy of Educational Sciences of Ukraine, October 17, 2019}

\section{Natalia Kulalaieva}

PhD in Chemistry, Associate Professor, Head of the Laboratory for Professional Training Technologies, Institute of Vocational Education and Training of the National Academy of Educational Sciences of Ukraine, Kyiv, Ukraine

Hanna Romanova

DSc in Pedagogy, Professor, Deputy Director for Scientific Work, Institute of Vocational Education and Training of the National Academy of Educational Sciences of Ukraine, Kyiv, Ukraine

Abstract. The report presents the results of a scientific study "Methodological basis of project technologies design for professional workers training of agricultural, construction and auto transport fields", performed by the staff of the Laboratory for Vocational Training Technologies of the Institute of Vocational Education of the National Academy of Educational Sciences of Ukraine during 2016-2018. Experience of application of project technologies in professional training of skilled workers is analyzed; the methodological bases of development of design technologies for their professional training are defined. Methodological approaches to project vocational training in the VET-schools are justified. The methods of development of project technologies of professional training of future skilled workers of agrarian, construction and motor transport industries, organization of project activity in the VET-schools, evaluation of the results of project professional training of students have been created. Project technologies for professional training of future skilled workers (information-analytical, practice-oriented, research-seeking, creative-innovative, social and educational) are presented. The experimental verification of their effectiveness is shown by studying the levels of readiness of pedagogical staff to develop and apply project technologies, and students - to the project vocational training.

Keywords: project technologies; vocational training; future skilled workers; project vocational training. 